\title{
曲線状繊維によって強化された複合材積層板の座屈解析*
}

\author{
本田真也*1, 大西良昌*2, 成田吉弘*3
}

\section{Buckling Analysis for Laminated Composite Plates Reinforced by Curvilinear Fibers}

\author{
Shinya HONDA*4, Yoshimasa OONISHI and Yoshihiro NARITA \\ *4 Division of Human Mechanical Systems and Design, Faculty of Engineering, Hokkaido University, \\ N 13 W 8, Kita-ku, Sapporo-shi, Hokkaido, 060-8628 Japan
}

\begin{abstract}
This paper proposes an analytical method for elastic buckling of laminated composite plates with local anisotropy induced by curved reinforcement fibers. The local anisotropy accounts for nonhomogenous stress distribution within the plate when it is subjected to in-plane loads along the boundary. An in-plane elasticity problem has to be solved first to determine the in-plane stresses, and these stresses become input to the buckling problem. Both in-plane and buckling problems are solved independently by using the Ritz method with algebraic polynomial displacement functions. In numerical results, the present results agree well with those from the finite element method, and the present plates with specific curvilinear fibers show higher buckling loads than plates with conventional straight fibers. It is therefore confirmed that the locally anisotropic plates with curvilinear fibers have strong possibility to improve the buckling performance over conventional materials with straight fibers.
\end{abstract}

Key Words : Buckling, Composite Material, Material Design, Local Anisotropy, Curvilinear Fiber, Ritz Method, Laminated Plate

\section{1. 緒言}

局所的な異方性を有する自然界の素材は，工業的に 製造される均質な人工材料より，その環境に対してよ り優れた特性を示すことが多い，例えば，牛の脊椎骨 には，血管や神経を通寸微小な穴があるが，穴周辺か ら亀裂が発生することはない，それは穴の接線方向に 配向している HAp の結晶方位が原因だと考えられて いる(1). 人工的な工業材料において, 同様に局所異方 性構造を実現することで，より効率的な構造材料の設 計が行える可能性は高い.

局所異方性を実現する材料として，著者らが注目し たのは，繊維強化複合材料である．近年，その生産技 術は大きく進歩しており，繊維の牽引方向を連続的に 変化させて, 曲線状の強化綫維を持つ材料の生産が可 能である(2). 局所的に力学特性の異なる板の解析に関 しては, $\operatorname{Martin}^{(3)} ら か ゙$ 初めて, 緘維の含有率を部材内 で変化させることで，局所的に異なる力学特性を持つ 複合材の振動解析を行った. Martin らは，Ritz法を用 いて局所的に繊維含有率を変化させた板の座屈強度を 解析し, 従来の一様な含有率を持つ板よりも優れた座

* 原稿受付 2009 年 9 月 24 日。

*1 正員, 北海道大学大学院工学研究院 (牢 060-8628 札幌市北 区北 13 条西 8)

*2 松山市役所(恶790-8571 松山市 2 番町 4-7-2).

*3 正員, フエロー, 北海道大学大学院工学研究院

E-mail : honda@eng.hokudai.ac.jp
屈破壊強度を有することを示している. Hyer ${ }^{(4)} ら は$ 有 限要素法の要素間にお引いて繊維配向角を連続的に变化 させることによって板の臨界座屈荷重值が向上するこ とを示している. 近年, Gürdal ${ }^{(2),(5)-7)} ら は ， 二$ 二点間の 角度を線形的に変化させることで，曲線状繊維を定義 し，その板が直線(平行)繊維によって強化された板よ りも優れた力学特性を示すことを実験, 解析を含めた 総合的な研究によって確認している，また，著者 ${ }^{(8)} ら$ は放物線状の綫維形状を有する複合材に関して, Ritz 法を用いて積層板の振動解析を行った. その結果, 曲 線状繊維によって強化された板は従来の直線瀻維を有 する板とは異なる振動特性を示し，曲線形状を最適に 設計することで，より高性能な板を設計し得ることを 示した.

局所的な力学特性を持つ板の最適化問題に関しては

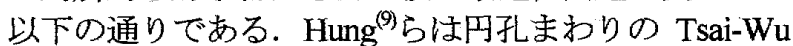
則の破壊強度を最大にするために，離散的な繊維分布

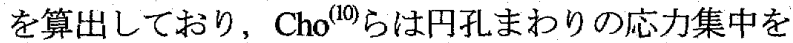
最小にする目的で䋐維の角度分布を算出している. Parnas ${ }^{(1)}$ らは，ベッセル関数を用いたスプライン関数 で連続した曲線形状瀻維と板表面を定義し，重量最小 化を目的とした設計手法を提案している. Setoodeh ${ }^{(12)}$ や Abdalla ${ }^{(13)} ら$ 積層パラメー夕を最適に分布する ことで, 最適な局所異方性構造を実現し, 局所異方性 板が優れたコンプライアンスや振動数を有しているこ

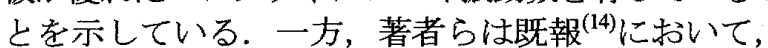


有限要素法の要素内に短繊維を最適に分布することで， 局所異方性を実現し，積層板の振動数最大化を目的と した最適化問題に取り組んだ. その結果, 局所的な異 方性を持つ板は従来の直線繊維板よりも, 高い振動数 を有することが明らかになった．また，それらを与え る短繊維の分布形には，ある傾向が見られた。 そのた め, 複合材の振動数最大化を目的として, 曲線状繊維 の形状をスプライン関数により表現し，その形状を最 適に設計した ${ }^{(15)}$. 結果より，曲線状繊維を有する板は 直線緘維板と同等，またはより高い固有振動数を有す ることがわかった。

本報では曲線状繊維を有する複合材積層板の線形座 屈解析を行う．一様応力下の薄板の固有振動数解析之 線形座屈解析は共に固有值問題となり類似しているが, 本報のように局所的な異方性を有する板に関しては， 圧縮荷重による非一様な応力分布を導出する必要があ る.そのため, 本解析では，初めに Ritz 法を用いて 面内応力の分布を平面応力問題として解き，その分布 形から得られたエネルギ(仕事)を用いて，さらに面外 の曲げ問題に対して Ritz 法により座屈解析を行った. Riz 法は有限要素法に比べて複雑な形状の表現力には 劣るが，パラメータスタディが容易であり、䋊維形状 やその近似の精度を簡便に変更できる特長を有してい る.こうした特長にも拘らず，Rit 法は曲げや座屈・ 振動解析などの面外たわみ問題には用いられるが, 面 内問題一応用される例は数少ない(3). 計算例において, 曲線状繊維によ゙り非均質な異方性を有する複合材板は， 均質な異方性を有する直線緎維板より，優れた座屈特 性を示すことを確認した。

\section{2. 応力解析之座屈解析手法}

2 -1 局所異方性板の剛性 図 1 に示すような曲 線状の強化繊維を有する層が中央面に関して対称に $2 N$ 枚積層された板を考える. 板抾法は $a \times b \times h(h$ 板 厚)であり，hは十分に小さく，平面応力状態に従うも の上する. 第 $k$ 層における任意の点 $p$ での䋊維(接線) 方向を 1 ，垂直方向を 2 とすると，各点における材料 主軸方向の応力ーひずみ関係は以下の式で表わされる。

$$
\left\{\begin{array}{l}
\sigma_{1} \\
\sigma_{2} \\
\tau_{12}
\end{array}\right\}=\left[\begin{array}{ccc}
Q_{11} & Q_{12} & 0 \\
Q_{12} & Q_{22} & 0 \\
0 & 0 & Q_{66}
\end{array}\right]\left\{\begin{array}{l}
\varepsilon_{1} \\
\varepsilon_{2} \\
\gamma_{12}
\end{array}\right\}
$$

ここで, $Q_{i j}(i, j=1,2,6)$ は剛性係数であり，材料主軸 方向の材料定数から以下のように定義できる.

$$
\begin{array}{ll}
Q_{11}=E_{1} /\left(1-v_{12} v_{21}\right), & Q_{22}=E_{2} /\left(1-v_{12} v_{21}\right), \\
Q_{12}=v_{21} Q_{11}=v_{12} Q_{22}, & Q_{66}=G_{12}
\end{array}
$$

ここで， $E_{1}, E_{2}$ はそれぞれの方向の弾性係数， $G_{12}$ はせ ん断弾性係数, $v_{12}, v_{21}$ は各方向のポアソン比である.

式(1)を第 $k$ 層の任意点 $p$ にお㚈る繊維配向角度 $\theta_{k} た ゙$ け座標変換することで, 点 $p$ における $\mathrm{O}-x y$ 座標に関 する応力ーひずみの関係を

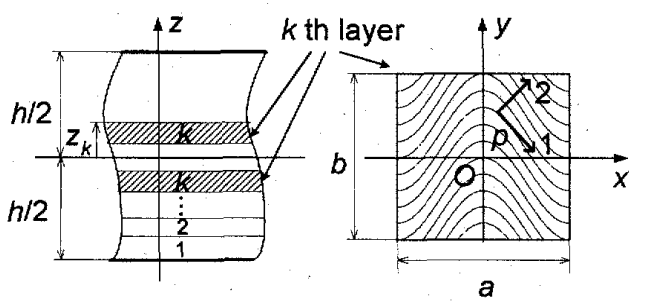

Fig. 1 The coordinate systems $O-x y z$.

$$
\left\{\begin{array}{l}
\sigma_{x} \\
\sigma_{y} \\
\tau_{x y}
\end{array}\right\}=\left[\begin{array}{lll}
\bar{Q}_{11} & \bar{Q}_{12} & \bar{Q}_{16} \\
\bar{Q}_{12} & \bar{Q}_{22} & \bar{Q}_{26} \\
\bar{Q}_{16} & \bar{Q}_{26} & \bar{Q}_{66}
\end{array}\right]\left\{\begin{array}{l}
\varepsilon_{x} \\
\varepsilon_{y} \\
\gamma_{x y}
\end{array}\right\}
$$

と表すことができる.ここで， $\bar{Q}_{i j}(i, j=1,2,6)$ は座標 変換された剛性係数であり, 弾性不変量 $U_{i}(i=1,2, \ldots$, 5)を用いて

$$
\left\{\begin{array}{l}
\overline{Q_{11}} \\
\overline{Q_{22}} \\
\overline{Q_{12}} \\
\overline{Q_{66}} \\
\overline{Q_{16}} \\
\overline{Q_{26}}
\end{array}\right\}=\left[\begin{array}{ccc}
U_{1} & \cos \theta_{k} & \cos 4 \theta_{k} \\
U_{1} & -\cos \theta_{k} & \cos 4 \theta_{k} \\
U_{4} & 0 & -\cos 4 \theta_{k} \\
U_{5} & 0 & -\cos 4 \theta_{k} \\
0 & \left(\sin 2 \theta_{k}\right) / 2 & \sin 4 \theta_{k} \\
0 & \left(\sin 2 \theta_{k}\right) / 2 & -\sin 4 \theta_{k}
\end{array}\right]\left\{\begin{array}{c}
1 \\
U_{2} \\
U_{3}
\end{array}\right\}
$$

と表わす.ただし，

$$
\left\{\begin{array}{l}
U_{1} \\
U_{2} \\
U_{3} \\
U_{4} \\
U_{5}
\end{array}\right\}=\left[\begin{array}{cccc}
3 / 8 & 3 / 8 & 1 / 4 & 1 / 2 \\
1 / 2 & -1 / 2 & 0 & 0 \\
1 / 8 & 1 / 8 & -1 / 4 & -1 / 2 \\
1 / 8 & 1 / 8 & 3 / 4 & -1 / 2 \\
1 / 8 & 1 / 8 & -1 / 4 & 1 / 2
\end{array}\right]\left\{\begin{array}{c}
Q_{11} \\
Q_{22} \\
Q_{12} \\
Q_{66}
\end{array}\right\}
$$

である， $\theta_{k}$ は，従来の直線緘維によって強化された均 質異方性板の場合は，各層において定数となるが，本 報で扱う曲線状繊維で強化された板に関しては，板内 の位置の関数亡なる.

積層板の全厚に対する合応力ーひずみ，および合モ ーメントー曲率の関係は, 式(3)を板厚に関して積分 することで求められる. 本報では対称積層に限定し， 面内一面外の連成は無視するため, 面内剛性 $A_{i j}(i, j=$ $1,2,6)$ おび曲け岡性 $D_{i j}$ は独立に考えることができ る. $z_{k}$ 第 $k$ 層の外面の $z$ 座標として, それぞれ以下 のようになる.

$$
\begin{aligned}
& A_{i j}=\sum_{k=1}^{N}\left(\overline{Q_{i j}}\right)_{k}\left(z_{k}-z_{k-1}\right) \\
& D_{i j}=\frac{1}{3} \sum_{k=1}^{N}\left(\overline{Q_{i j}}\right)_{k}\left(z_{k}^{3}-z_{k-1}^{3}\right)
\end{aligned}
$$

$2 \cdot 2$ 局所異方性板の面内応力分布 ${ }^{(3)}$ 境界に沿つ て面内荷重または強制変位が与えられる板の弾性解析 において，面内応力を求めるには，(1)つり合いの式， (2)ひず办の適合条件，(3)境界条件の三つを満足する関 数を求める必要がある. しかしながら，本解析では各 点において, 䋊維配向角度およひ甽性が位置座標に依 存する関数となるため, 直接に応力分布を算出するの 
は困難である，そのため，Ritz 法を用いて変位分布を 算出し，その後に面内の応力分布を求める. なお応力 分布は，式(の)により積層板に対して得られた剛性を 有する等価な板モデルにおける分布であり，各層ごと の応力值ではない，しかし本論文で扱う座屈は，弾性 的な全体座屈であり，等価な板モデルの剛性と面内荷 重による仕事から座屈荷重值が求められる.

面内の変位を求めるために, $x, y$ それぞれの方向の 変位を $u v$ とし，変位関数を以下のように仮定する.

$$
\begin{gathered}
u(\xi, \eta)=\sum_{i=0}^{I} \sum_{j=0}^{J} P_{i j} X_{i}(\xi) Y_{j}(\eta) \\
v(\xi, \eta)=\sum_{k=0}^{K} \sum_{l=0}^{L} Q_{k l} X_{k}(\xi) Y_{l}(\eta) \\
(i, j, k, l=0,1,2, \ldots, I, J, K, L)
\end{gathered}
$$

ここで, $P_{i j}, Q_{k l}$ は未定係数であり, $\xi=2 x / a$ および $\eta$ $=2 y / b$ は無次元化座標である. $X_{i}(\xi), Y_{j}(\eta), X_{k}(\xi)$, $Y_{l}(\eta)$ は「境界条件インデックス」(16)用いて, 境界上 で幾何学的境界条件の任意の組合せを満足する関数で あり，以下のように定義する。

$$
\begin{aligned}
& X_{i}(\xi)=\xi^{i}(1+\xi)^{b u 1}(1-\xi)^{b u 3} \\
& Y_{j}(\eta)=\eta^{j}(1+\eta)^{b u 2}(1-\eta)^{b u 4} \\
& X_{k}(\xi)=\xi^{k}(1+\xi)^{b v 1}(1-\xi)^{b v 3} \\
& Y_{l}(\eta)=\eta^{I}(1+\eta)^{b v 2}(1-\eta)^{b v 4}
\end{aligned}
$$

ここで, $b u 1, b u 2, b u 3, b u 4$ は $u$ に関する, $b v 1, b v 2, b v 3$, $b v 4$ はvに関する長方形板の各辺での境界条件インデ ックスである. 各添字は長方形の左辺を第 1 辺として, 反時計周りに第 2 4 辺としている. また, 境界条件 インデックスの值が 1 の場合は, そのインデックスが 示寸辺上で変位が必ず 0 となり, 固定辺を表現する. 0の場合は自由辺を表す。

面内荷重を受ける板の全ポテンシャルエネルギは,

$$
V=V_{S}-V_{L}
$$

となる.ここで $V_{S}$ は面内伸縮によるひずみエネルギ

$$
V_{S}=\frac{1}{2} \iint_{A}\left(\sigma_{x} \varepsilon_{x}+\sigma_{y} \varepsilon_{y}+\tau_{x y} \gamma_{x y}\right) d A
$$

であり，式(3)および式(の)の第一式を代入して，

$$
\begin{gathered}
V_{S}=\frac{1}{2} \iint_{A}\left\{A_{11}\left(\frac{\partial u}{\partial x}\right)^{2}+2 A_{12}\left(\frac{\partial u}{\partial x}\right)\left(\frac{\partial v}{\partial y}\right)\right. \\
+A_{22}\left(\frac{\partial v}{\partial y}\right)^{2}+A_{66}\left(\frac{\partial v}{\partial x}+\frac{\partial u}{\partial y}\right)^{2}+ \\
\left.2 A_{16}\left(\frac{\partial u}{\partial x}\right)\left(\frac{\partial v}{\partial x}+\frac{\partial u}{\partial y}\right)+2 A_{26}\left(\frac{\partial v}{\partial y}\right)\left(\frac{\partial v}{\partial x}+\frac{\partial u}{\partial y}\right)\right\} d A
\end{gathered}
$$

となる.ここで, 変位とひずみの関係,

$$
\varepsilon_{x=}=\frac{\partial u}{\partial x}, \varepsilon_{y}=\frac{\partial v}{\partial y}, \tau_{x y}=\frac{\partial v}{\partial x}+\frac{\partial u}{\partial y}
$$

を用いた．また， $V_{L}$ は荷重による仕事で，

$$
\begin{aligned}
& V_{L}=\int_{-b / 2}^{b / 2}\left[N_{1} u\right]_{x=-\alpha / 2} d y+\int_{-b / 2}^{b / 2}\left[-N_{3} u\right]_{x=a / 2} d y \\
& +\int_{-a / 2}^{a / 2}\left[N_{2} v\right]_{y=-b / 2} d x+\int_{-a / 2}^{a / 2}\left[-N_{4} v\right]_{y=b / 2} d x
\end{aligned}
$$

である.ここで， $N_{1}, N_{2}, N_{3}, N_{4}$ は，長方形の境界に沿 って作用する荷重である，それぞれの添字は境界条件 と同様である. 式(11), (13)から得られる, 汎関数 $V$ (全 ポテンシャルエネルギ)の極值を以下の式により求め ることで, $u$ およびvを求めることができる.

$$
\begin{aligned}
& \frac{\partial V}{\partial P_{i j}}=0 \quad(i, j=1,2, \ldots, I, J) \\
& \frac{\partial V}{\partial Q_{k l}}=0 \quad(k, l=1,2, \ldots, L, K)
\end{aligned}
$$

得られた変位から，式(12)および式(6),(3)を用いて，面 内のひずみおよび合灾力がそれぞれ求まる.

本解析では，式(13)の積分と式(11)の y 方向の積分は, 解析的に行うことが可能である. しかしながら，式 (11)の $x$ 方向の積分は面内剛性 $A_{i j}$ が, 板内の位置に依 存した煩雑な関数となり，解析的に積分することがで きない.そのため, 数值積分を用いてひずみエネルギ の算出を行った.

$2 \cdot 3$ 局所異方性板の座屈解析 面内問題之同様 に，Ritz 法を用いて座屈荷重值および座屈モードを算 出する. 面外変位 $w$ を式(7)と同椂に，

$$
\begin{gathered}
w(\xi, \eta)=\sum_{m=0}^{M} \sum_{n=0}^{N} R_{m n} X_{m}(\xi) Y_{n}(\eta) \\
(m, n=0,1,2, \ldots, M, N)
\end{gathered}
$$

と定義する. ここで, $R_{m n}$ は未定係数であり, $X_{m}(\xi)$, $Y_{n}(\eta)$ も面内問題と同様に,

$$
\begin{aligned}
& X_{m}(\xi)=\xi^{m}(1+\xi)^{b w 1}(1-\xi)^{b w 3} \\
& Y_{n}(\eta)=\eta^{n}(1+\eta)^{b w 2}(1-\eta)^{b w 4}
\end{aligned}
$$

と定義する. ただし，面外変位の境界条件インデック ス( $(b w 1, b w 2, b w 3, b w 4)$ は，0のとき自由，1のとき単 純支持，20とき固定端を示す点が面内問題と異なる。 寸なわちインデックス值が 2 のとき， $w$ を一階微分し てもその辺上でたわみ角，及びたわみを常に 0 とでき るため固定辺を表す．1のときは，wのみが常に 0 と なり単純支持辺となる.

面外変形に伴う板の全ポテンシャルエネルギは,

$$
U=U_{S}-U_{L}
$$

となる.ここで， $U_{S}$ は，曲げ変形によるひずみエネ ルギで,

$$
\begin{aligned}
& U_{S}= \frac{1}{2} \iint_{A}\left\{D_{11}\left(\frac{\partial^{2} w}{\partial x^{2}}\right)^{2}+2 D_{12}\left(\frac{\partial^{2} w}{\partial x^{2}}\right)\left(\frac{\partial^{2} w}{\partial y^{2}}\right)\right. \\
&+D_{22}\left(\frac{\partial^{2} w}{\partial y^{2}}\right)^{2}+4 D_{16}\left(\frac{\partial^{2} w}{\partial x^{2}}\right)\left(\frac{\partial^{2} w}{\partial x \partial y}\right) \\
&\left.+4 D_{26}\left(\frac{\partial^{2} w}{\partial y^{2}}\right)\left(\frac{\partial^{2} w}{\partial x \partial y}\right)+4 D_{66}\left(\frac{\partial^{2} w}{\partial x \partial y}\right)^{2}\right\} d A
\end{aligned}
$$


である.ここでも同様に $D_{i j}(i, j=1,2,6)$ は面内の位置 座標に依存する面外剛性係数である.

面内荷重による仕事(エネルギ) $U_{L}$ は, 面内弾性解析 で求めた各合応力分布 $\sigma_{x}, \sigma_{y}, \tau_{x y}$ を用いて, 以下のよ うになる.

$$
\begin{aligned}
U_{L}=\frac{h}{2} \iint_{A}\left\{\sigma_{x}\left(\frac{\partial w}{\partial x}\right)^{2}\right. & +\sigma_{y}\left(\frac{\partial w}{\partial y}\right)^{2} \\
& \left.+\tau_{x y}\left(\frac{\partial w}{\partial x}\right)\left(\frac{\partial w}{\partial y}\right)\right\} d A
\end{aligned}
$$

各積分計算は, 式(18)の $y$ 方向のみ解析的に行い, そ の他は数値的に行った.

無次元化したエネルギ式(18)，(19)を式(17)に代入し， 汎関数の極值を求めることで, 無次元化した座屈固有 值(座屈パラメータ)גを求めることができる.

$$
\lambda=N_{4} a^{2} / D_{0}
$$

ここで, $D_{0}=E_{2} h^{3} / 12\left(1-v_{12} v_{21}\right)$ は基準とした曲げ剛 性である.

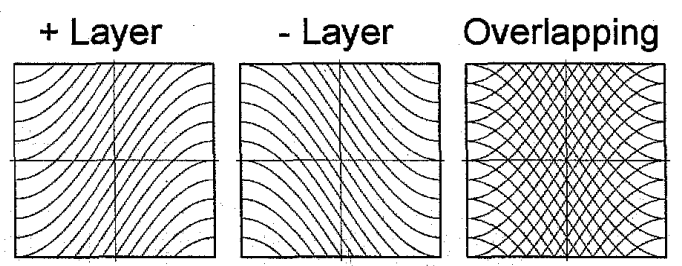

(a) Sine function
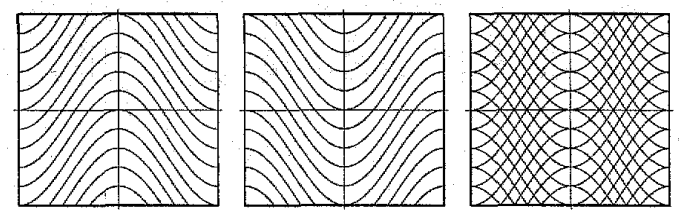

(b) Cosine function
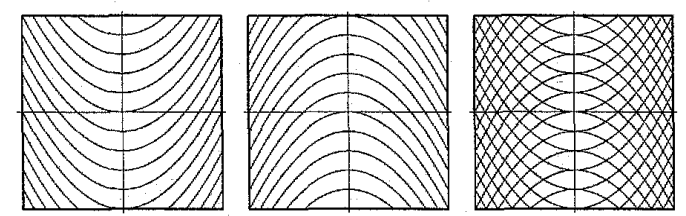

(c) Quadratic function

Fig. 2 Fiber shapes expressed by (a) sine function, (b) cosine function, and (c) quadratic function.

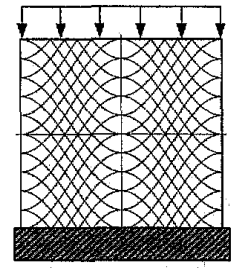

Type 1

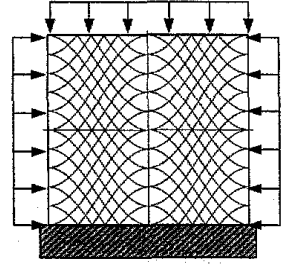

Type 2
Fig. 3 In-plane boundary conditions for Type 1 and 2 .
Table 1 Boundary condition indexes for Type 1 and Type 2.

\begin{tabular}{lll}
\hline B. C. & Type 1 & Type 2 \\
\hline$N_{l}, N_{2}, N_{3}, N_{4}$ & $0,0,0,1$ & $1,0,1,1$ \\
$b u 1, b u 2, b u 3, b u 4$ & $0,1,0,1$ & $0,1,0,1$ \\
$b v 1, b v 2, b v 3, b v 4$ & $0,1,0,0$ & $0,1,0,0$ \\
\hline
\end{tabular}

\section{3. 数値計算結果および考察}

3-1 面内応力解析結果 本報では CFRP (graphite/epoxy)に関して計算を行う. 弾性定数は, $E_{1}$ $=138 \mathrm{GPa}, E_{2}=8.96 \mathrm{GPa}, G_{12}=7.1 \mathrm{GPa}, v_{12}=0.30$ とする. 面外の境界条件( $b w 1, b w 2, b w 3, b w 4)$ は，四つの文字で定 義し， $\mathrm{S}$ は単純支持，C甶固定を表す。

繊維形状は $x$ 座標に関する一価関数に限定し，図 2 に示寸三つの形状を採用した．それぞれの形状は，無 次元化座標 $(O-\xi \eta ;-1 \leq \xi, \eta \leq 1)$ 内において, 以下の 式で表現できる.

$$
\begin{aligned}
& \text { (a) } \eta=\sin \left(\frac{\pi}{2} \xi\right)+C \\
& \text { (b) } \eta=\frac{1}{2} \cos (\pi \xi)+C \\
& \text { (c) } \eta=x^{2}+C
\end{aligned}
$$

形状(a)は，既報(15)において，積層板の基本振動数を最 大化する目的で，全周固定(CCCC)板を最適化した際 に得られた最適な繊維形状を $\sin$ 関数で近似した繊維 形状である. 形状(b)は $\cos$ 関数により表現した．既報 (15)より，基本振動数を最大化する最適な緎維形状は固 定端に対して繊維が垂直に配向する傾向が明らかとな ったため, 左右(第 1 辺，第 3 辺)端の付近で境界に対 して垂直で, さらに左右対称の形状になる関数を選ん だ. 形状(c)は二次関数状の曲線繊維である. 他の二つ の形状とは異なり，左右辺に対してある角度を持って 繊維が斜向する．また，式(21)で表現した繊維形状を

「層」と定義し，それと水平軸に関して対称な形状 を「一層」と定義する．図 2 には，各層の形状とそれ を重祆合わせた際の，図を示した。
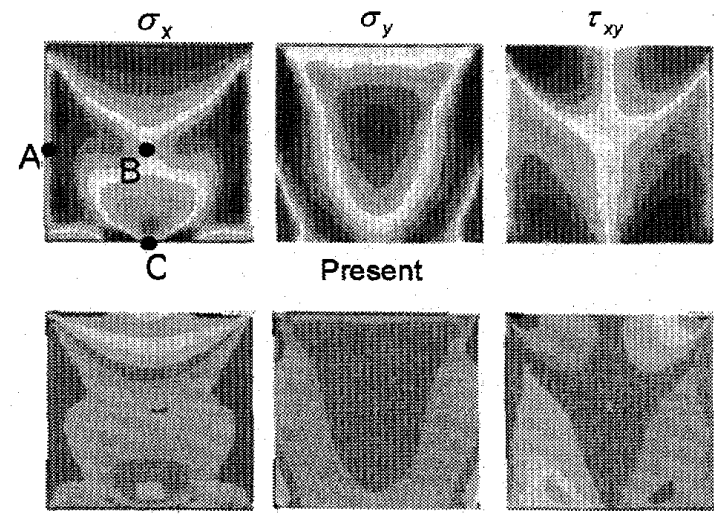

FEM

Fig. 4 In-plane stress distributions for the single layer plate with (c) quadratically shaped fibers under Type 2 boundary condition. 
Table 2 Stresses in each direction at points A, B, and C indicated in Fig. 2.

\begin{tabular}{rrrrrrr}
\hline & \multicolumn{3}{c}{ Present } & \multicolumn{3}{c}{ FEM } \\
\cline { 2 - 7 } & \multicolumn{1}{c}{$\sigma_{x}$} & \multicolumn{1}{c}{$\sigma_{y}$} & \multicolumn{1}{c}{$\tau_{x y}$} & \multicolumn{1}{c}{$\sigma_{x}$} & \multicolumn{1}{c}{$\sigma_{y}$} & $\tau_{x y}$ \\
\hline A & -72.7 & -214 & 0.175 & -100 & -152 & 1.02 \\
B & -76.6 & -7.89 & 0 & -80.8 & -40.8 & 0 \\
C & -27.5 & -91.7 & 0 & -56.0 & -121 & 0 \\
\hline
\end{tabular}

面内の変位と荷重の境界条件を図 3 に示す．本報で は，第 2 辺で一辺を固定し，第 4 辺に沿って一定の一 軸圧縮を受ける境界条件と，第 1,3，4辺に沿って二軸 圧縮を受ける境界条件を採用した。一軸圧縮を受ける 条件を Type1，二軸圧縮を受㞴る条件を Type2 とする。 表 1 にそれぞれの面内の境界条件インデックスを示す. 表 1 のインデックスは, 長方形の第 1 4 辺の順に与 えている.インデックスが 1 は，その自由度を固定す る，または荷重が加わっていることを意味しており， ０は自由辺または荷重が負荷されていない，また，外 部荷重による仕事に対応するエネルギ分布を算出する ことが目的なため，荷重は単位值としている，

図 4 に，本手法により求めた単層板の面内応力分布 $\left(\sigma_{x}, \sigma_{y}, \tau_{x y}\right)$ と, 有限要素法(FEM)により求めた分布を示 す. FEM の結果の算出には, 沉用 FEM コードの ANSYS を用いた. FEM では要素中心座標を用いて求 めた繊維配向角度を各要素に個別に与え, 曲線形状を 離散化し線形近似した. 纎維は(c)二次関数形状であり, 境界条件は Type2 とした. 両手法とも最大・最小応力 值を 10 等分したコンター図で示している. FEMでは 最大・最小応力発生点で大きな応力集中が生じており， 両者の差が大きい，そのため，本手法と比較して，板 の中央付近では応力值の差が小さく, 色の薄い部分の 面積が大きくなっている.これらの部分の応力值を比 較するため，表 2 に両手法で求められた三点(図 4 の $\mathrm{A}, \mathrm{B}, \mathrm{C})$ 応力值を示寸. $\sigma_{x}, \tau_{x y}$ は両手法とも近い值 を与えているが， $\sigma_{y}$ では差が大きくなっている。

これは $\sigma_{y}$ に関する FEM による応力計算では，板 の両下隅で大きな応力集中が起こっていたことが 原因と考えられる。しかしながら，両手法が与え る応力の分布形はよく一致している。主た，応力 分布は繊維形状を反映した分布となっており，直 線繊維や等方性板とはことなる分布である.

3.2 座届解析結果本手法により算出された単 層板の座屈荷重值と, FEM 解析結果の比較を表 3 に 示す. 繊維形状は(c)二次関数形状である. Type 1 の全 周単純支持(SSSS)の場合に両手法の差が最大で $7.7 \%$ となっているが，他の条件ではよく一致した值を与え ている. また, 図 5 に Type 2, (c)二次関数形状の緎維 に関する，本手法が与える座屈モードと FEM が与え る座屈モードをそれぞれ示す，両手法の結果は類似し たモード形状を与えており，繊維形状を反映して歪ん でいる.

対称 8 積層板の CCCC および SSSS の座屈解析の結 果孝それぞれ図 6 に示す。積層構成は $[+/-1+/-] \mathrm{s}$ のア
ングルプライ，および既報 ${ }^{(17)}$ において求められた最 適な積層構成を参照した $[+/-1-1-] \mathrm{s}$ とした. また，比 較のため, 直線繊維板 $\left( \pm 45^{\circ}\right),\left(0^{\circ} / 90^{\circ}\right)$ の結果も示す.

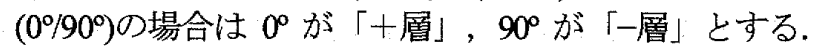
例えば， $\left(0^{\circ} / 90^{\circ}\right) の[+/-1-/-] \mathrm{s}$ は $\left[0^{\circ} / 90^{\circ} / 90^{\circ} / 90^{\circ}\right] \mathrm{s}$ となる.

CCCC では, $[+1-1-1-] \mathrm{s}$ の(b)cos 関数形状が最も高い 座屈荷重值与えている. 直線䋊維板の最適積層構成で ある， $\left(0^{\circ} / 90^{\circ}\right) の[+/-1-1-] \mathrm{s}^{(17)}$ よりも $4.9 \%$ 高い座屈荷重 值を与えていることより，曲線状繊維の優位性が確認 できた。

SSSS では(c)二次関数状繊維の $[+/-/ / /-] \mathrm{s}$ が直線繊維 板よりもわずかに高い荷重值を与えている. SSSS の 場合は $[+/-1+/-] \mathrm{s}$ と $[+/-1-1-] \mathrm{s}$ がほぼ同様の值を与えて いることから，内側の層による座屈荷重值への影響付 わずかであることがわかる。

Table 3 Buckling parameters for the single layer plates with (c) quadratically shaped fibers under Type 2 boundary condition.

\begin{tabular}{ccccc}
\hline $\begin{array}{c}\text { B. C. } \\
\text { (In-plane) }\end{array}$ & $\begin{array}{c}\text { B. C. } \\
\text { (Out-of-plane) }\end{array}$ & Present & FEM & $\begin{array}{c}\text { Dif. } \\
(\%)\end{array}$ \\
\hline \multirow{2}{*}{ Type 1 } & SSSS & 207.4 & 223.4 & -7.7 \\
& CCCC & 429.9 & 428.8 & 0.26 \\
Type 2 & SSSS & 117.6 & 121.8 & -3.6 \\
& CCCC & 286.8 & 275.4 & 4.0 \\
\hline
\end{tabular}

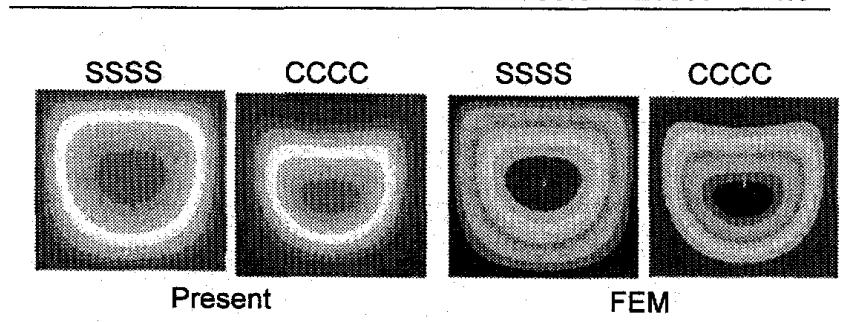

Fig. 5 Buckling mode shapes for totally simply supported and clamped single layer plates with (c) quadratically shaped fibers under Type 2 boundary condition.

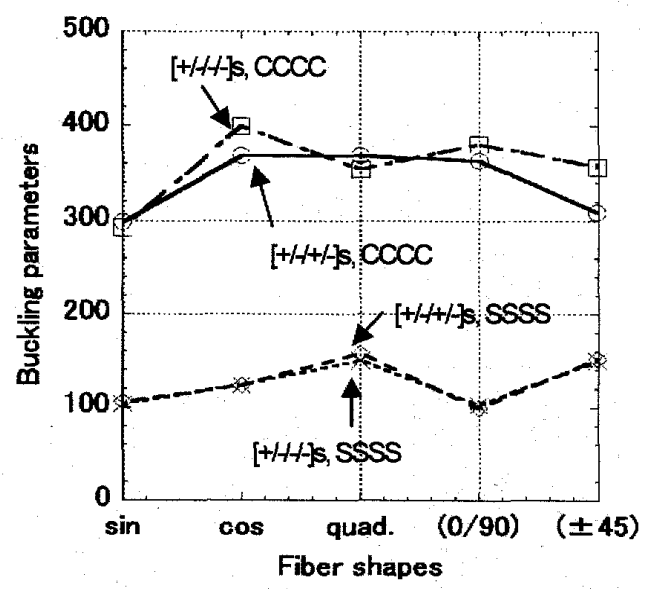

Fig. 6 Buckling parameters for the CCCC and SSSS square plates with curvilinear fibers and straight fibers under Type 2 boundary conditions. 
(a) $\sin$

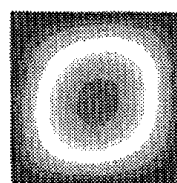

(b)cos

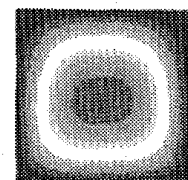

SSSS $[+/-1+/-]$ s

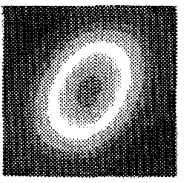

(c)quadratic
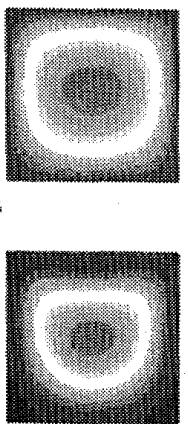

$\operatorname{cccc}[+/-1+/-] \mathrm{s}$

Fig. 7 Buckling modes for the CCCC and SSSS square plates with curvilinear fibers under Type 2 boundary conditions.

また，基本振動数の最大化問題では最適な形状であ った(a)sin 関数は，境界条件によらず他の緎維形状よ りも低い座屈荷重值を与えていた。これより，曲線状 繊維により強化した場合，座屈と振動の間にトレード オフの関係があることが分かる.

図 7 にアングルプライ $[+/ / / /-] \mathrm{s}$ を有する曲線状絨維 板の座屈モードを示す. 各モードは, 図 5 と同様にそ れぞれ緎維形状を反映したモードとなっているが，歪 みの大きさは「一層」の影響で小さくなっている。

以上の点より, 曲線状瀻維板は, 局所的に材料主軸 方向を変化させることで，千一ドの形状に合わせて柔 軟に剛性方向を分布できる．例えば，直線繊維よりも 高い座屈荷重值を与えた $\cos$ 関数形状(図 3)依，固定 端付近では端に垂直に，モード形状の勾配部分(左右 端と中心線の間)では繊維が角度を持って交差して配 向しており，またモードのピーク付近では水平に配向 している.このように岡性を局所的に分布させた結果， より高い座屈荷重值が得られたと推測できる.

\section{4. 結言}

数值結果より, 本手法は汎用 FEM とよく一致した座 屈荷重值および座屈モードを与えた。座屈モードは曲 線状緎維を反映して，等高線が歪む形状となった，特 に曲線状繊維板は，最適な積層構成を有する直線(平 行)䋊維板よりも高い座屈荷重值を与え，局所異力性板 が座屈変形に対して優位性を持つことが確認できた。

本手法は，FEMのように要素毎に線形近似するの ではなく, Ritz 法を用いることで曲線繊維の効果を連 続的に考慮できる。しかしながら，最適化問題に適用 するためには，さらに数值積分の計算時間の短縮が望 ましい.

\section{参考文献}

(1) Giri, B., Tadano, S., Fujisaki, K. and Todoh, M., Microstructure of bone around natural hole in bovine lumber vertebra, Journal of Biomechanical Science and Engineering, Vol. 2, No. 1 (2007), pp. 1-11.

(2) Lopes, C. S., Gürdal, Z. and Camanho, P. P., Variable-stiffness composite panels: Buckling and first-ply failure improvements over straight-fibre laminates, Computers \& Structures Vol. 86 (2008), pp. 897-907.

(3) Martin, A. F. and Leissa, A. W., Application of the Ritz method to plane elasticity problems for composite sheets with variable fiber spacing, International Journal of Numerical Method in Engineering, Vol. 28, No. 8 (1989), pp. 1813-1825.

(4) Hyer, M. H. and Lee, H. H., The use of curvilinear fiber format to improve buckling resistance of composite plates with central circular holes, Composite Structures, Vol. 18 (1991), pp.239-261.

(5) Gürdal, Z. and Olmedo, R., In-plane response of laminates with spatially varying fiber orientation: variable stiffness concept, AIAA Journal, Vol.31, No. 4 (1993), pp. 751-758.

(6) Güdal, Z., Tatting, B. F. and Wu, C. K., Variable stiffness composite panels: effects of stiffness variation on the in-plane and buckling response, Composites Part A, Vol. 39, No. 6 (2008), pp. 911 922.

(7) Lopes, C. S., Camanho, P. P. and Güdal, Z., Tatting, B. F., Progressive failure analysis of tow-placed, variable-stiffness panels, International Journal of Solids and Structures, Vol. 44 (2007), pp. 8493-8516.

(8) Honda, S., Oonishi, Y., Narita, Y. and Sasaki, K., Vibration analysis of composite rectangular plates reinforced along curved lines, Journal of System, Design and Dynamics, Vol. 2, No. 1 (2008), pp. 7682.

(9) Hung, J. and Haftka, R. T., Optimization of fiber orientations near a hole for increased load-carrying capacity of composite laminates, Structural Multidisciplinary Optimization, Vol. 30 (2005), pp. 335-341.

(10) Cho, H. K. and Rowlands, R. E., Reducing tensile stress concentration in perforated hybrid laminate by genetic algorithm, Composite Science and Technology, Vol. 67 (2007), pp. 2877-2883.

(11) Parnas, L., Oral, S. and Ceyhan, Ü., Optimum design of composite structures with curved fiber courses, Composites Science and Technology, Vol. 63 (2003), pp. 1071-1082.

(12) Setoodeh, S., Abdalla, M. M. and Gürdal, Z., Design of variable-stiffness laminates using lamination parameters, Composites Part B: Engineering, Vol. 37 (2006), pp.301-309.

(13) Abdalla, M. M., Setoodeh, S. and Gürdal, Z., Design of variable stiffness composite panels for maximum fundamental frequency using lamination parameters, Composite structures, Vol. 81, No. 2 (2007), pp. 283291.

(14) Honda, S. and Narita, Y., Design for the maximum natural frequency of laminated composite plates by optimally distributed short fibers, Journal of System Design and Dynamics, Vol. 2, No. 6, (2009), pp. 1195-1205.

(15) Honda, S., Narita, Y. and Sasaki, K., Maximizing the fundamental frequency of laminated composite plates with optimally shaped curvilinear fibers, Transactions of the Japan Society of Mechanical Engineers, Series $C$, Vol.75, No.753 (2009), pp.1244-1250 (in Japanese).

(16) Narita, Y., Layerwise optimization for the maximum fundamental frequency of laminated composite plates, Journal of Sound and Vibration, Vol. 263 (2003), pp. 1005-1016.

(17) Honda, S. and Narita, Y., Buckling optimization of laminated composite plates by minimizing errors of the discrete lamination parameters, Transactions of the Japan Society of Mechanical Engineers, Series A, Vol.72, No.720 (2006), pp. 1262-1269 (in Japanese). 